\title{
Mercury Accumulation and Elimination in Different Tissues of Zebrafish (Danio rerio) Exposed to a Mercury-Supplemented Diet
}

\author{
Hugo C. Vieira (D), Andreia C. M. Rodrigues (D), Amadeu M. V. M. Soares (D), Sizenando Abreu \\ and Fernando Morgado *
}

Citation: Vieira, H.C.; Rodrigues, A.C.M.; Soares, A.M.V.M.; Abreu, S.; Morgado, F. Mercury Accumulation and Elimination in Different Tissues of Zebrafish (Danio rerio) Exposed to a Mercury-Supplemented Diet. J. Mar. Sci. Eng. 2021, 9, 882. https:// doi.org/10.3390/jmse9080882

Academic Editor: Dan Tchernov

Received: 19 July 2021

Accepted: 12 August 2021

Published: 16 August 2021

Publisher's Note: MDPI stays neutral with regard to jurisdictional claims in published maps and institutional affiliations.

Copyright: (c) 2021 by the authors. Licensee MDPI, Basel, Switzerland. This article is an open access article distributed under the terms and conditions of the Creative Commons Attribution (CC BY) license (https:// creativecommons.org/licenses/by/ $4.0 /)$.
CESAM - Centre for Environmental and Marine Studies, Department of Biology, University of Aveiro, 3810-193 Aveiro, Portugal; hugovieira@ua.pt (H.C.V.); rodrigues.a@ua.pt (A.C.M.R.); asoares@ua.pt (A.M.V.M.S.); siz@ua.pt (S.A.)

* Correspondence: fmorgado@ua.pt

\begin{abstract}
In this study, we evaluated the bioaccumulation of mercury in zebrafish (Danio rerio) exposed to mercury-contaminated food for 21 days and the depuration of mercury for a subsequent post-exposure period of 28 days. Four tissues (muscle, liver, gills, and skin) were analyzed for mercury content. Overall, data indicated that $\mathrm{Hg}$ accumulation in the liver is faster than in other tissues. Furthermore, the liver is the tissue with the highest accumulation rate per day $\left(0.021 \mu \mathrm{g} \mathrm{Hg} \mathrm{g}^{-1} \mathrm{day}^{-1}\right)$, followed by muscle, skin, and gills. Conversely, the $\mathrm{Hg}$ depuration rates in different tissues showed the following order: gills $>$ skin $>$ muscle $>$ liver. The bioaccumulation factor values of liver and muscle increased linearly during the uptake period. The ratios between mercury concentration in liver and muscle during the experiment also increased during the uptake period and remained higher than 1 during the elimination period, suggesting that Danio rerio needed more than 4 weeks of depuration. Finally, the distribution of $\mathrm{Hg}$ in the water column during the accumulation period is $\mathrm{Hg}$ particulate $>\mathrm{Hg}$ dissolved, and during the depuration period it is the opposite, mercury particulate $<$ mercury dissolved. In conclusion, this study contributes to a better understanding of the differences in $\mathrm{Hg}$ dynamics during the accumulation and depuration stages in a model fish, also emphasizing the alterations on $\mathrm{Hg}$ available in the water column.
\end{abstract}

Keywords: mercury dietary intake; liver:muscle ratio; bioaccumulation factor; particulate mercury; dissolved mercury

\section{Introduction}

Mercury $(\mathrm{Hg})$ is one of the most toxic elements found in the environment due to its persistence, bioaccumulation, and lack of biological functions [1,2]. In addition to these characteristics, $\mathrm{Hg}$ has been recognized as deleterious to human and ecosystem health even at low concentrations [3]. This trace element occurs naturally in the environment as a result of natural processes of emission, including erosion of mineral deposits, volcanic emissions and forest fires. However, $\mathrm{Hg}$ concentrations have greatly increased in the last decades due to anthropogenic activities such as the discharge of industrial effluents, wastes from mining activities, and combustion of fuels [4,5].

After the accident in Minamata and Niigata, Japan, $\mathrm{Hg}$ contamination and its effects on the environment and humans became a real concern [6], especially in aquatic ecosystems, as $\mathrm{Hg}$ bioaccumulates and biomagnifies throughout all levels of the food chain [7]. In aquatic systems, Hg may be present in particulate (suspension or sediment in the bottom) or dissolved forms, being constantly redistributed between these phases [8]. $\mathrm{Hg}$ can be accumulated by fish and other aquatic organisms by different routes: water exposure through gills or skin and dietary exposure through the ingestion of particulate matter and/or contaminated food [9-11]. Dietary exposure to $\mathrm{Hg}$ can lead to its accumulation in all fish tissues [12] and can affect its growth, reproduction, and neural function [13]. Differences in the accumulation levels in different organs of a fish can primarily be attributed 
to differences in the physiological role of each organ [14]. However, the accumulated concentrations in fish depend on the amount and type of food ingested, the age, size, and especially the trophic level $[15,16]$. Considerable variation in fish total $\mathrm{Hg}$ concentrations can also occur in estuaries and other transitional habitats defined by complex biogeochemical and ecological gradients [17]. Fish age is an important factor due to possible changes in food choices, the time of exposure to $\mathrm{Hg}$, and the decrease in the gross growth efficiency [18]. Other biotic parameters such as the growth in biomass can lead to a decrease in the $\mathrm{Hg}$ concentration, this effect known as growth dilution. Therefore, the exposure time and the rate of metabolism or clearance of each tissue are biotic factors that need to be considered [18]. Furthermore, some abiotic factors can influence the bioavailability and bioaccumulation patterns of $\mathrm{Hg}$ in fish, as well as can increase biomethylation. Dissolved organic carbon plays an important role in the transport and bioavailability of both organic and inorganic $\mathrm{Hg}$, with a positive correlation between the amount of dissolved organic carbon available in the water column and the $\mathrm{Hg}$ accumulation in muscle frequently reported [19]. Particulate matter in suspension also functions as a carrier of $\mathrm{Hg}$ as it binds to inorganic and organic particles or biota such as bacteria, algae, and plankton [20].

Mercury tends to be accumulated in detoxification organs such as the liver and kidney [21], although fish muscle is the most analyzed tissue to evaluate $\mathrm{Hg}$ accumulations as it seems to function as a $\mathrm{Hg}$ reservoir in order to protect other organs [22], in addition to being the main fish tissue consumed by humans [23]. Muscle has been reported to enhance long-term bioaccumulation due to the increased capacity to accumulate $\mathrm{Hg}$ when compared to the other organs. Conversely, the liver has the ability to metabolize large amounts of $\mathrm{Hg}$ from the environment and also plays an important role in storage, redistribution, and detoxification [24]. Gills and skin accumulate considerable levels of toxicants through direct contact with contaminated water and through its respiratory, osmotic, and ionic regulatory functions $[25,26]$. In spite of this, dietary mercury exposure usually only causes sublethal toxic effects, even after prolonged feeding with highly contaminated foods [27]. In contrast with the bioaccumulation processes, elimination of $\mathrm{Hg}$ from fish tissues is slow [28,29], which promotes $\mathrm{Hg}$ biomagnification throughout the food chain, ultimately representing a risk for the human population [30,31]. Therefore, the presence of $\mathrm{Hg}$ in seafood continues to pose a public health concern, with fish consumption as the major route for $\mathrm{Hg}$ exposure in humans [32,33]. Zebrafish (Danio rerio) have been used as biological model for environmental toxicology research due to the relatively small size of the adult fish and the external fertilization and transparency during development, characteristics that permit a large number of samples and simple laboratory management [21,34]. In the context of the dietary $\mathrm{Hg}$ exposure assessment, the use of zebrafish is highly relevant due to Danio rerio homologies to humans [21,34]; they have heart chambers that rhythmically pump oxygen-carrying blood through the body, they have eyes with a retinal structure, a liver, pancreas, kidneys and intestines, backbone, and more than $80 \%$ of their genes have human counterparts [35]. The $\mathrm{Hg}$ accumulation and elimination dynamics in different tissues due to dietary fish exposure could have a toxicological and/or nutritional approach and purpose, emphasizing differences in physiological functions and among the main organs' role in these processes. The use of a zebrafish model is useful to compare effects and mechanisms of toxicity and to elucidate the degree of specificity and differences in $\mathrm{Hg}$ accumulation and elimination in different fish organs during the uptake period. The present study aimed to evaluate $\mathrm{Hg}$ bioaccumulation dynamics in the muscle, liver, gills, and skin of zebrafish during the contamination and depuration periods. More specificially, the study aimed to (i) compare differences in the condition index and $\mathrm{Hg}$ accumulation in the different tissues during the sampling periods; (ii) examine the $\mathrm{Hg}$ accumulation during the uptake period and the $\mathrm{Hg}$ elimination during the elimination period in the different tissues; and (iii) compare the $\mathrm{Hg}$ liver/muscle ratio between the uptake and elimination periods. 


\section{Materials and Methods}

\subsection{Experimental Conditions and Adult Fish Assay}

Adult zebrafish Danio rerio (body weight: $278.6 \mathrm{mg}$ ww; standard length $30.2 \mathrm{~mm}$; and $n=48$ ) were obtained from the zebrafish facility established at the Biology Department of the University of Aveiro (Portugal). Throughout the acclimation and experimental period, temperature was maintained at $22 \pm 1{ }^{\circ} \mathrm{C}, \mathrm{pH} 7.5 \pm 0.5$, conductivity at $750 \pm 50 \mu \mathrm{S} \mathrm{cm}^{-1}$, and a photoperiod of $16 \mathrm{~h} / 8 \mathrm{~h}$ light/dark.

Based on OECD guideline number 305 [36], each fish was isolated in a tank (400 mL) with permanently oxygenated water and were individually fed twice a day for 21 days (uptake period) on ZM fish food 400 (Zebrafish Management Ltd., Winchester, UK) supplemented in the laboratory with mercuric chloride $\left(5.7 \mu \mathrm{g} \mathrm{Hg} \mathrm{g}^{-1}\right)$, followed by an elimination period (28 days) on ZM fish food 400 not $\mathrm{Hg}$ supplemented. All organisms were isolated to provide equal amounts of food during the study and avoid food competition. The daily amount of food corresponded approximately to $2 \%$ of the fish wet weight. Therefore, each fish was weekly exposed to about $170 \mathrm{ng}$ of $\mathrm{Hg}$ via food ingestion. Throughout the experiment, a control group (Ctr) fed with uncontaminated food (ZM 400) was used.

Every 7 days (at 7, 14, 21, 28, 35, 42, and 49 days) six tanks were randomly selected and the fish of each tank was removed and euthanized by decapitation under ice-cold induced anesthesia. Each fish was dissected on ice and the skeletal muscle, liver, gills, and skin were independently collected. All collected samples (muscle, liver, and gills) were stored in individual Eppendorf tubes properly identified and stored at $-20{ }^{\circ} \mathrm{C}$ for later $\mathrm{Hg}$ quantification. In addition, the dissolved and particulate $\mathrm{Hg}$ in each tank sampled was quantified. For this process, the water of each tank was filtered using Millipore filters of $0.45 \mu \mathrm{m}$. Subsequently, filters were oven-dried at $35^{\circ} \mathrm{C}$ overnight, weighed, and stored until the $\mathrm{Hg}$ analysis. The filtrate was acidified with $\mathrm{HNO}_{3}$ (Merck, $\mathrm{Hg}$-free) to obtain a $\mathrm{pH}<2$ and then stored at $4{ }^{\circ} \mathrm{C}$ until the dissolved $\mathrm{Hg}$ analysis.

\subsection{Mercury Quantification}

Mercury quantification was performed using the Advanced Mercury Analyzer (AMA254, made by ALTEC and distributed by LECO). This technique of $\mathrm{Hg}$ quantification does not require previous sample digestion [37]. The procedure is based on a pyrolysis process of the sample using a combustion tube heated at $750{ }^{\circ} \mathrm{C}$ under an oxygen atmosphere. The released $\mathrm{Hg}$ is then trapped in a gold amalgamator and subsequently detected and quantified by atomic absorption spectrometry. The detection limit of the AMA-LECO 254 analyzer is $0.01 \mathrm{ng} \mathrm{Hg}$. The entire analytical procedure was validated by analyzing three standard biological reference materials, namely DORM-3 (Fish Protein Certified Reference Material for Trace Metals, National Research Council of Canada, Ottawa, ON, Canada), DOLT-3 (Dogfish Liver Certified Reference Material for Trace Metals, National Research Council of Canada, Ottawa, ON, Canada), and TORT-2 (Lobster Hepatopancreas Reference Material for Trace Metals, National Research Council of Canada, Ottawa, ON, Canada) at the beginning and end of each set, ensuring that the instrument remained calibrated throughout the study. The obtained data $\left(0.4 \pm 0.02 \mu \mathrm{g} \mathrm{g}^{-1}\right.$ of $\mathrm{Hg}$ for DORM3, $3.31 \pm 0.09 \mu \mathrm{g} \mathrm{g}^{-1}$ of $\mathrm{Hg}$ for DOLT-3, and $0.31 \pm 0.01 \mu \mathrm{g} \mathrm{g}^{-1}$ of Hg for TORT-2) and reference values of $\mathrm{Hg}\left(0.38 \pm 0.06 \mu \mathrm{g} \mathrm{g}^{-1}\right.$ for DORM-3, $3.37 \pm 0.14 \mu \mathrm{g} \mathrm{g}^{-1}$ for DOLT-3, and $0.27 \pm 0.06 \mathrm{\mu g} \mathrm{g}^{-1}$ for TORT-2) were not statistically different $(p>0.05)$.

\subsection{Bioaccumulation Factor}

The bioaccumulation factor (BAF) was calculated as the ratio of $\mathrm{Hg}$ concentration in the fish tissue divided by the $\mathrm{Hg}$ concentration provided in the diet [38]. If $\mathrm{BAF}>1$, it indicates that the organism/tissue has the potential to accumulate the metal [39]. The BAF was calculated according to Viana et al. [40] using the equation:

$$
\mathrm{BAF}=\frac{[\mathrm{Hg}] \text { in fish tissue }}{[\mathrm{Hg}] \text { in provided food }}
$$




\subsection{Statistical Analysis}

Data normality was verified through the Kolmogorov-Smirnov test. Data followed a normal distribution, thus, the parametric statistical test of one-way ANOVA was used. A pairwise multiple comparison procedure (Dunnett's test) was used to compare differences in the condition index and the $\mathrm{Hg}$ accumulation in the different tissues at different sampling times. In addition, linear regressions were used to examine the $\mathrm{Hg}$ accumulation during the uptake period and the $\mathrm{Hg}$ elimination during the elimination period in the different tissues. A $t$-test was used for the comparison of the $\mathrm{Hg}$ liver/muscle ratio between the uptake and elimination periods. Statistical analyses were performed using GraphPad Prism (version 6.01). Statistical significance was defined as $p<0.05$. $\mathrm{Hg}$ concentration data are presented as mean value \pm standard error value (mean $\pm \mathrm{SE}$ ).

\section{Results and Discussion}

The weight-length relationship is a practical index widely used for the evaluation of the fish condition under experimental conditions [41]. According to Morgan [42], a poor condition index (CI) is usually associated with deficient feeding and/or inadequate environmental conditions, thus, potentially increasing mortality rates. The $\mathrm{CI}$ obtained for Danio rerio individuals used in this study (Figure 1 ) shows that the organisms were well adapted to the experimental conditions, as no significant differences $(p>0.05)$ in CI during the trial period were observed.

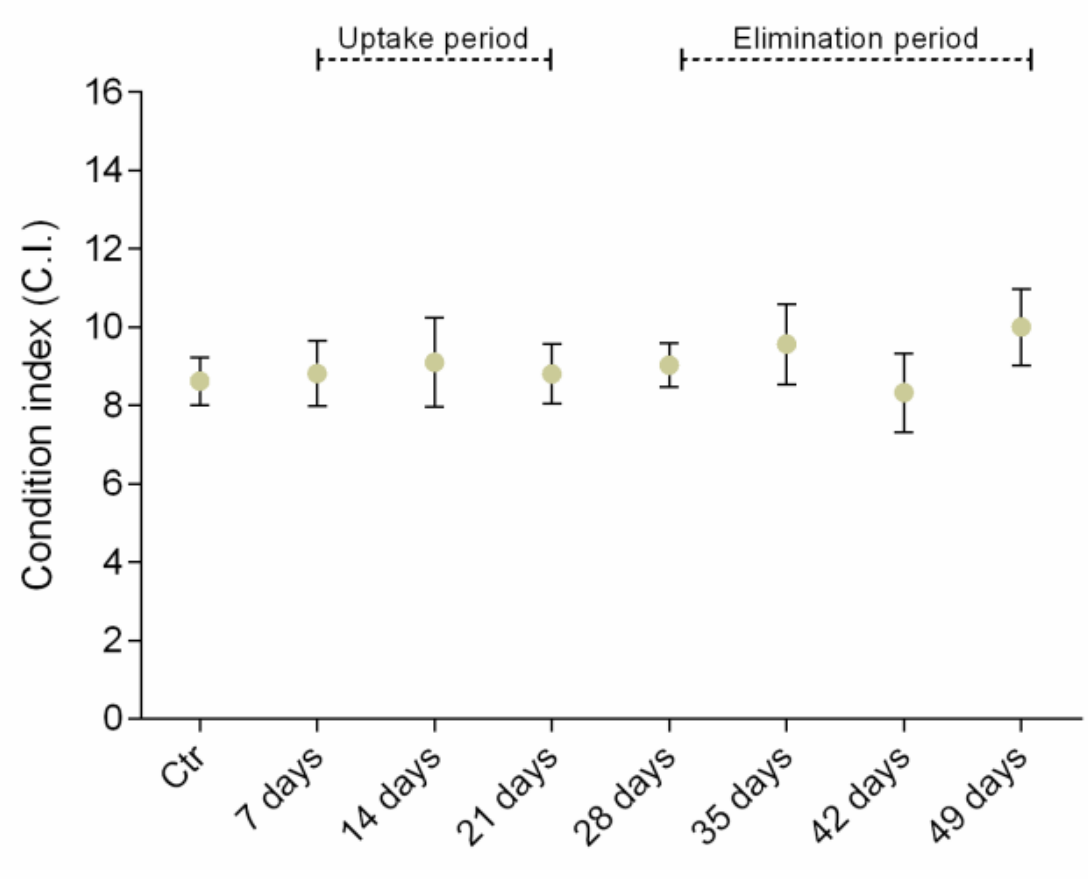

\section{Experiment duration}

Figure 1. Condition index (CI) of Danio rerio organisms through the experimental period.

Considering the $\mathrm{Hg}$ accumulation in the different tissues (Figure 2), it was observed that $\mathrm{Hg}$ accumulated differently between liver, muscle, gills, and skin. During the exposure period, liver (Figure 2a) showed a time and dose-dependent increase in $\mathrm{Hg}$ content, which agrees with previous studies [22,43]. For instance, Oliveira Ribeiro et al. [22] observed this relationship in the skeletal muscle of Danio rerio after 7, 21, and 63 days of dietary exposure (13.5 $\left.\mathrm{ug} \mathrm{g}^{-1}\right)$ and James et al. [43] observed this relationship in catfish (Heteropneustes fossilis) exposed to two $\mathrm{Hg}$ concentrations ( 0.01 and $0.03 \mu \mathrm{g} \mathrm{g}^{-1}$ ) during 9 days. Moreover, at day 21 (last week of the uptake period), the levels of $\mathrm{Hg}$ present in the liver of fish fed with a Hg-enriched diet $\left(0.45 \pm 0.08 \mu \mathrm{g}^{-1}\right)$ were significantly higher $(p<0.05)$ when compared to 
the levels of $\mathrm{Hg}\left(0.25 \pm 0.02 \mu \mathrm{g}^{-1}\right)$ present in the liver of fish from the control treatment (not $\mathrm{Hg}$ supplemented diet). Regarding the first week of depuration (day 28), the $\mathrm{Hg}$ present in the liver $\left(0.24 \pm 0.03 \mu \mathrm{g}^{-1}\right)$ decreased to levels close to those found in the control treatment fish $\left(0.25 \pm 0.02 \mu \mathrm{g}^{-1}\right)$. This reduction in $\mathrm{Hg}$ content in the liver reflects the dietary shift from $\mathrm{Hg}$-enriched food to non-enriched food. Regarding the $\mathrm{Hg}$ accumulation in the muscle (Figure 2b), it is possible to observe a slight (and non-significant) increase with time during the uptake period. Interestingly, the maximum accumulation of $\mathrm{Hg}$ in the muscle was observed after the end of the exposure period, more precisely one week later (day 28). At this sampling point, the $\mathrm{Hg}$ concentration in the muscle of exposed fish was significantly higher than that observed in the muscle of the control treatment $\left(0.47 \pm 0.05 \mu \mathrm{g}^{-1}\right.$ and $0.25 \pm 0.03 \mu \mathrm{g}^{-1}$, respectively).
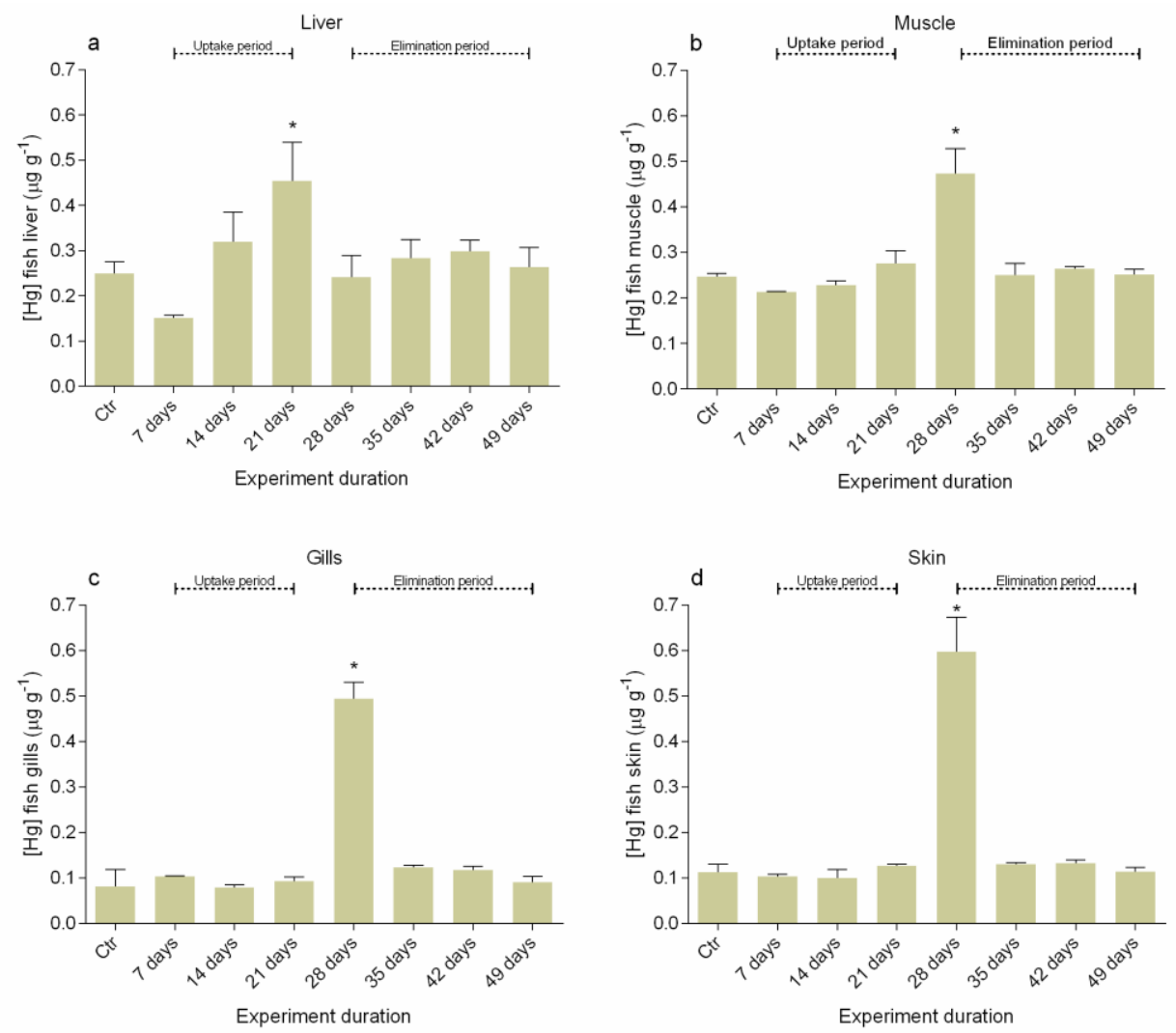

Figure 2. Evaluation of the $\mathrm{Hg}$ concentration $\left(\mu \mathrm{g} \mathrm{g}^{-1} \mathrm{ww}\right)$ in the: (a) liver, (b) muscle, (c) gills, and (d) skin of Danio rerio during the experimental period. An asterisk $\left(^{*}\right)$ denotes a significant difference compared with the control treatment (Ctr).

Regarding $\mathrm{Hg}$ accumulation in the gills (Figure 2d), no significant differences $(p<0.05)$ were found between the $\mathrm{Hg}$ levels found during the uptake period and the $\mathrm{Hg}$ levels from the control treatment. Nevertheless, a peak of $\mathrm{Hg}$ was observed at the beginning of the depuration period (day 28). This increase was statistically significant $(p<0.05)$ when compared with the levels of $\mathrm{Hg}$ present in the gills of fish from the control treatment. Similarly, the skin tissue also showed the same pattern of $\mathrm{Hg}$ accumulation observed in muscle and gills, reaching a maximum concentration of $0.59 \pm 0.08 \mu^{-1}$ at day 28 .

Considering the uptake period from day 7 to day 21, overall data indicate that $\mathrm{Hg}$ accumulation differs from tissue to tissue. Liver showed the highest accumulation rate, $0.021 \mu \mathrm{g} \mathrm{Hg} \mathrm{g}^{-1}$ day $^{-1}\left([\mathrm{Hg}]=0.0212 \mathrm{X}+0.0123, \mathrm{R}^{2}=0.871\right)$, followed by muscle at $0.008 \mu \mathrm{g} \mathrm{Hg} \mathrm{g}^{-1}$ day $^{-1}\left([\mathrm{Hg}]=0.008 \mathrm{X}+0.118, \mathrm{R}^{2}=0.835\right)$ and then the skin with an accumulation rate of $0.004 \mu \mathrm{g} \mathrm{Hg} \mathrm{g}^{-1} \mathrm{day}^{-1}\left([\mathrm{Hg}]=0.004 \mathrm{X}+0.041, \mathrm{R}^{2}=0.762\right)$, whereas the gills presented the lowest value of $0.003 \mu \mathrm{g} \mathrm{Hg} \mathrm{g}{ }^{-1}$ day $^{-1},([\mathrm{Hg}]=0.003 \mathrm{X}+0.1002$, $\left.\mathrm{R}^{2}=0.577\right)$. The variation in the $\mathrm{Hg}$ accumulation between these tissues can be supported 
by differences in their physiological functions [44]. For example, the liver experiences high metabolic activity $[45,46]$, playing a crucial role in the redistribution, detoxification, and transformation of $\mathrm{Hg}$ [24], and therefore is the organ that first reflects environmental contamination [47]. In contrast, the muscle tissue has a low metal detoxification capacity [48] and is known to reflect a long-time exposure to pollutants [49]. Thus, the observed late $\mathrm{Hg}$ accumulation in muscle, gills, and skin in relation to the liver is not surprising. Indeed, previous studies also revealed a delay in the accumulation of dietary $\mathrm{Hg}$ in muscle of amberjack (Seriola dumerili) [38] and zebrafish (Danio rerio) [50,51]. According to Van Walleghen et al. [52], this may be related to the fact that the $\mathrm{Hg}$ accumulating in the muscle may have been transferred from the liver.

When considering the sampling time between day 35 and day 49 (elimination period), it is possible to observe that the liver and muscle (Figure 2a,b, respectively) presented a $\mathrm{Hg}$ concentration significantly higher $(p<0.05)$ than the gills (Figure $2 c$ ) and skin (Figure 2d). Oliveira Ribeiro et al. [53] justifies the possibility of continuing to observe higher levels of $\mathrm{Hg}$ in the liver even after the exposure period as a result of a $\mathrm{Hg}$ redistribution from blood and other tissues. As stated above, the higher levels of $\mathrm{Hg}$ observed in the muscle may be related to the muscles' low metal-scavenging capacity. Contrary to what was observed for the accumulation phase, the skin and gills are the tissues with the highest elimination rate $\left(-0.02 \mu \mathrm{g} \mathrm{Hg} \mathrm{g}^{-1}\right.$ day $^{-1}$ and $-0.017 \mu \mathrm{g} \mathrm{Hg} \mathrm{g}^{-1}$ day $^{-1}$, respectively). According to Abreu et al. [54], considering the skin is in direct contact with the environment, it can play an important role in the elimination of heavy metals, acting as an excretory organ. James et al. [43] suggests that $\mathrm{Hg}$ can be lost from gill tissues faster than from other tissues, possibly through direct contact with the ambient medium.

In this study, no correlation between muscle and liver $\mathrm{Hg}$ levels was found during the uptake period $\left(\mathrm{R}^{2}=0.06 ; p>0.05\right)$ or in the elimination period $\left(\mathrm{R}^{2}=0.01 ; p>0.05\right)$. During the uptake period, an increase in the $\mathrm{Hg}$ liver/muscle ratio was observed with the experiment time (Figure 3). Despite this, no significant differences $(p>0.05)$ were found between sampling days. In contrast, during the elimination period, the values obtained for the liver/muscle ratio are similar; however, there seems to be a tendency to decrease over time. Nevertheless, looking at the liver/muscle ratio of $\mathrm{Hg}$ concentration from all individuals sampled in the uptake period and elimination period, significant differences between those periods were detected $(p<0.05)$, with values of $1.30 \pm 0.23$ and $0.95 \pm 0.09$, respectively.

The ratio between the $\mathrm{Hg}$ levels observed in the liver and muscle can indicate the exposure history of fish. For instance, a ratio is expected to be lower than 1 in fish with long-term exposure, while in fish with recent exposure, it should be higher than 1 [55]. Data from the literature indicate that the liver/muscle ratio of $\mathrm{Hg}$ concentrations in fish from contaminated areas (recent and higher $\mathrm{Hg}$ exposure) is higher than the liver:muscle ratio in fish from uncontaminated areas $[1,24,56]$.

Considering the bioaccumulation factor (BAF) values calculated for the different tissues (Table 1), liver and muscle presented higher values than those calculated for the gills and skin in both periods of the experiment. The exception is on day 28 (first week of the elimination period), during which the gills and skin showed high BAF values and were in line with what was observed in Figure 2. 


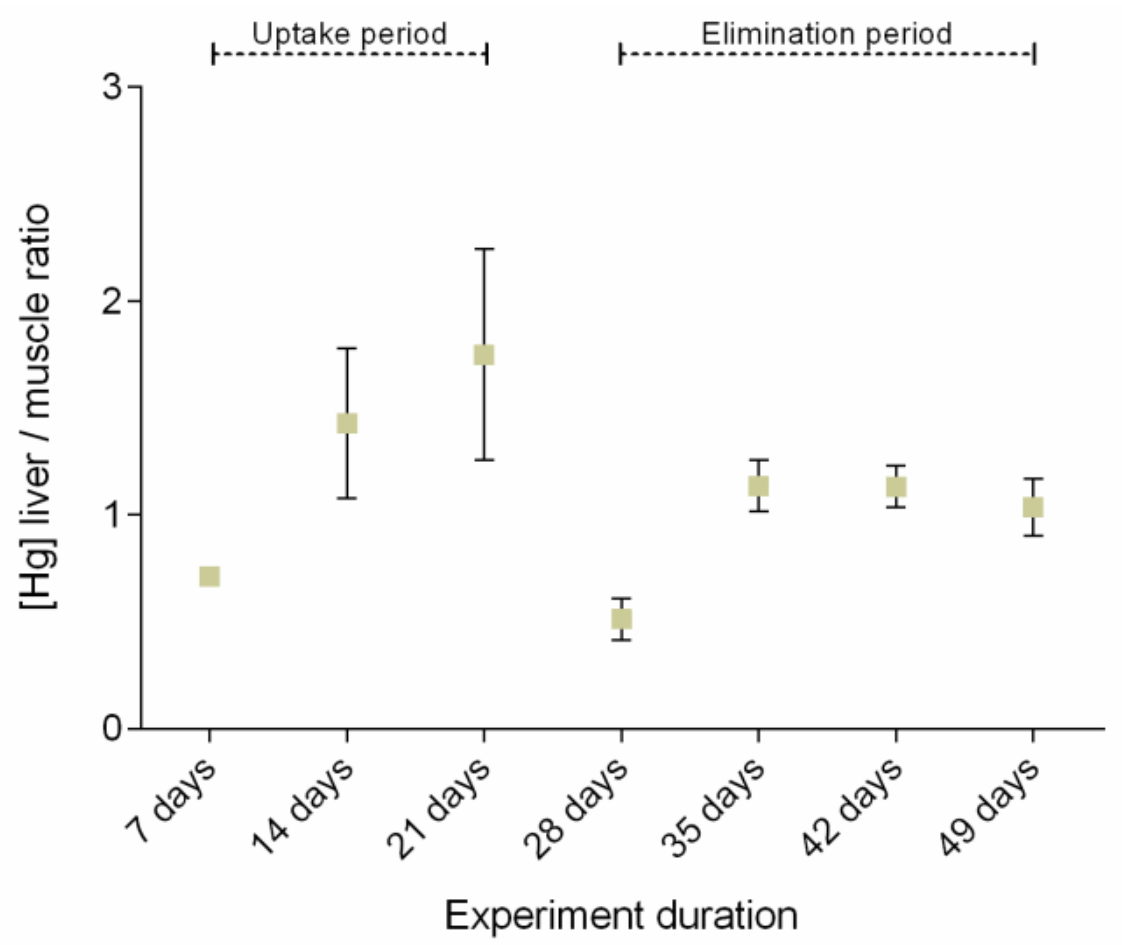

Figure 3. Ratio between the $\mathrm{Hg}$ concentration in the liver and muscle in the sampling periods (uptake and elimination period).

Table 1. Bioaccumulation factors of different tissues at different sampling periods of the uptake period.

\begin{tabular}{cccc}
\hline \multirow{2}{*}{ Tissue } & \multicolumn{3}{c}{ Uptake Period } \\
\cline { 2 - 4 } & Day 7 & Day 14 & Day 21 \\
\hline Liver & $0.89 \pm 0.38$ & $1.88 \pm 0.51$ & $2.67 \pm 0.28$ \\
Muscle & $1.25 \pm 0.01$ & $1.34 \pm 0.05$ & $1.62 \pm 0.17$ \\
Skin & $0.61 \pm 0.02$ & $0.59 \pm 0.10$ & $0.74 \pm 0.02$ \\
Gills & $0.61 \pm 0.01$ & $0.46 \pm 0.03$ & $0.55 \pm 0.05$ \\
\hline
\end{tabular}

In this study, we do not have physiological evidence to support the theory that the difference in the accumulation levels in different organs of a fish can primarily be attributed to the differences in the physiological role of each organ [14]. Nevertheless, the observed differences between tissues are in line with Karlsson et al. [57] who concluded that BAF values depend on which parts or tissues of the organism are examined.

Regarding the concentrations of dissolved and particulate $\mathrm{Hg}$ measured in the water column of the experimental tanks (Figure 4), the results demonstrate a significant increase $(p<0.05)$ in the amount of $\mathrm{Hg}$ in the particulate fraction during the sampling times of the uptake phase compared to the control treatment. The increase in the $\mathrm{Hg}$ load observed during the uptake period in the particulate fraction is likely to be related to the presence of $\mathrm{Hg}$-enriched food that was rejected by the fish and by the presence of feces. It is possible that part of the accumulated $\mathrm{Hg}$ can be incorporated into feces [58]. This possibility has already been supported by other studies with marine species such as Nigro et al. [59] who estimated that the amount of $\mathrm{Hg}$ eliminated through feces by bottlenose dolphins varied between $34 \%$ and $48 \%$ of the dietary intake. King and Davies [60] also demonstrated that the increase in $\mathrm{Hg}$ concentration observed in the sediments may be related to the particles excreted by the mussels (pseudo-feces). Conversely, during the elimination period there was a decrease in the amount of $\mathrm{Hg}$ associated with the particulate fraction and an increase in the amount of $\mathrm{Hg}$ associated with the dissolved fraction. The distribution of $\mathrm{Hg}$ in the water column in the uptake period was particulate $\mathrm{Hg}>$ dissolved $\mathrm{Hg}$. During the 
depuration period, this relationship had been reversed to particulate $\mathrm{Hg}<$ dissolved $\mathrm{Hg}$. This shift likely occurred because fish in the elimination period were fed with non- $\mathrm{Hg}$ supplemented food. Furthermore, the elimination of $\mathrm{Hg}$ accumulated during the uptake period to the water column by the gills may also be contributing to a greater amount of $\mathrm{Hg}$ in the dissolved fraction. According to Garnero et al. [48], gills can play an important role in $\mathrm{Hg}$ elimination.

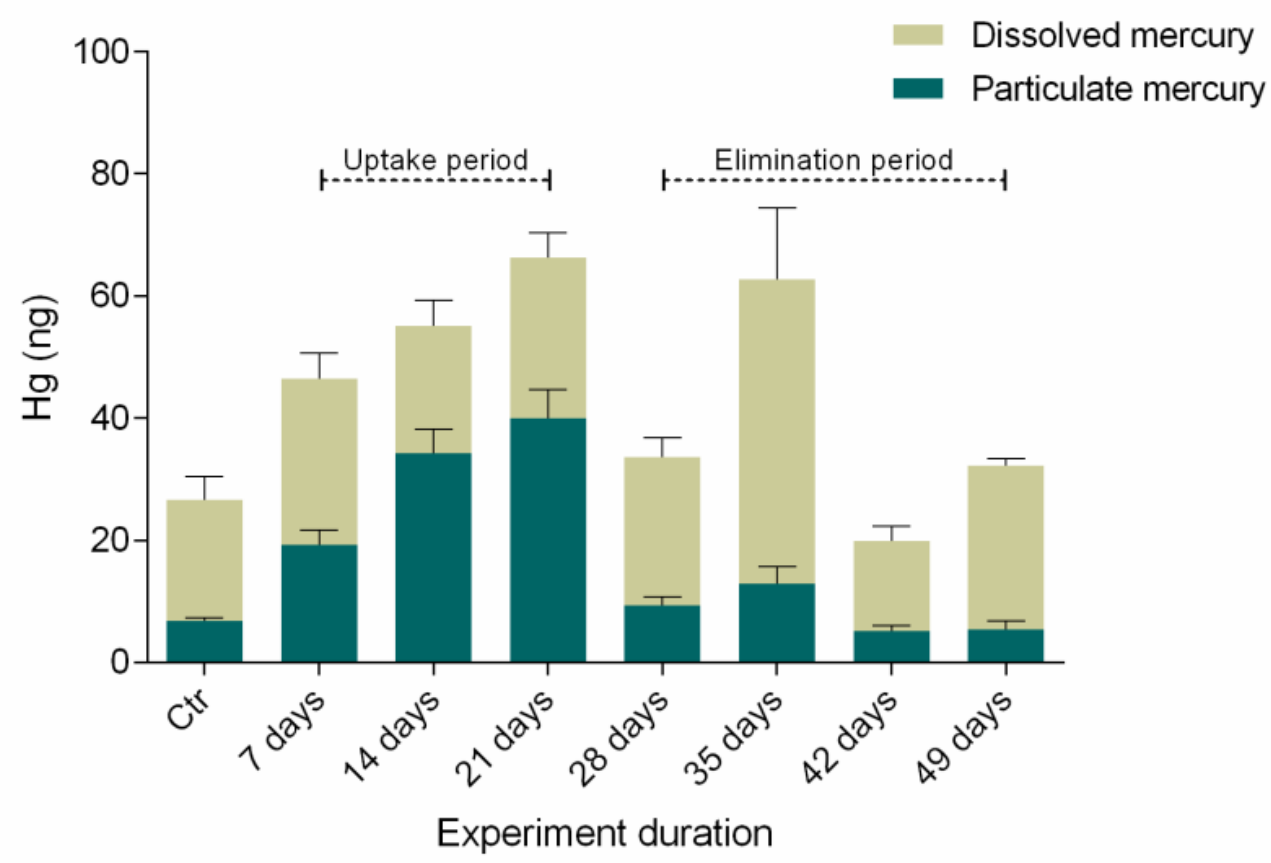

Figure 4. Comparison between the quantities of dissolved $\mathrm{Hg}$ and particulate $\mathrm{Hg}$ in the water column during the uptake period (21 days) and elimination period (from 28 to 49-day), and the control (Ctr).

\section{Conclusions}

The present study highlights that the liver is the organ that first reflects the environmental contamination, presenting the highest rates of accumulation during the uptake period. However, the elimination period showed that Danio rerio liver's ability to eliminate $\mathrm{Hg}$ is slow. In addition, this study showed that for a 3-week exposure to mercury, Danio rerio needs more than 4 weeks of depuration. The analysis of the $\mathrm{Hg}$ partitioning in the water column also suggests indirect evidence for the role of thr gills and skin as possible routes of $\mathrm{Hg}$ depuration. Furthermore, the $\mathrm{Hg}$ accumulation pattern observed in the different tissues studied suggest differences in the physiological functions and degree of organ specificity. Nevertheless, further studies focusing on cellular alterations caused by $\mathrm{Hg}$ accumulation and depuration are needed to clarify these raised questions.

Author Contributions: Conceptualization, F.M. and S.A.; methodology, F.M. and S.A.; formal analysis, H.C.V. and A.C.M.R.; investigation, H.C.V. and A.C.M.R.; resources, A.M.V.M.S.; writingoriginal draft preparation, H.C.V.; writing-review and editing, A.C.M.R., A.M.V.M.S., S.A. and F.M.; supervision, F.M. and S.A.; project administration, F.M., S.A. and A.M.V.M.S.; funding acquisition, F.M. and A.M.V.M.S. All authors have read and agreed to the published version of the manuscript.

Funding: This research was funded through CESAM (UIDP/50017/2020 + UIDB/50017/2020), with financial support from FCT/MEC through national funds.

Institutional Review Board Statement: The current study was led by accredited researchers of the Portuguese National Authority for Animal Health (DGAV_Direção Geral de Alimentação e Veterinária) for the practice of animal experimentation (FELASA Category B), following Portuguese Law number 113/2013 and the European Directive 2010/63/EU of the European Parliament and European Union Council on the protection of animals used for scientific purposes. 
Informed Consent Statement: Not applicable.

Data Availability Statement: The data presented in this study is available in the current manuscript and raw data is available on request from the corresponding author.

Conflicts of Interest: The authors declare that they have no conflict of interests (financial or non-financial).

\section{References}

1. Abreu, S.; Pereira, E.; Vale, C.; Duarte, A. Accumulation of mercury in sea bass from a contaminated lagoon (Ria de Aveiro, Portugal). Mar. Pollut. Bull. 2000, 40, 293-297. [CrossRef]

2. Pereira, E.; Abreu, S.N.; Coelho, J.P.; Lopes, C.B.; Pardal, M.A.; Vale, C.; Duarte, A.C. Seasonal fluctuations of tissue mercury contents in the European shore crab Carcinus maenas from low and high contamination areas (Ria de Aveiro, Portugal). Mar. Pollut. Bull. 2006, 52, 1450-1457. [CrossRef]

3. Hajeb, P.; Jinap, S.; Ismail, A.; Fatimah, A.B.; Jamilah, B.; Abdul Rahim, M. Assessment of mercury level in commonly consumed marine fishes in Malaysia. Food Control 2009, 20, 79-84. [CrossRef]

4. Ruelas-Inzunza, J.; Hernández-Osuna, J.; Páez-Osuna, F. Organic and total mercury in muscle tissue of five aquatic birds with different feeding habits from the SE Gulf of California, Mexico. Chemosphere 2009, 76, 415-418. [CrossRef]

5. Gray, J.E.; Hines, M.E. Biogeochemical mercury methylation influenced by reservoir eutrophication, Salmon falls creek reservoir, ID, USA. Chem. Geol. 2009, 258, 157-167. [CrossRef]

6. Gochfeld, M. Cases of mercury exposure, bioavailability, and absorption. Ecotoxicol. Environ. Saf. 2003, 56, 174-179. [CrossRef]

7. Kehrig, H.A.; Costa, M.; Moreira, I.; Malm, O. Total and methylmercury in a Brazilian estuary, Rio de Janeiro. Mar. Pollut. Bull. 2002, 44, 1018-1023. [CrossRef]

8. Canu, D.; Rosati, G. Long-term scenarios of mercury budgeting and exports for a Mediterranean hot spot (Marano-Grado Lagoon, Adriatic Sea). Estuar. Coast. Shelf Sci. 2016, 198, 518-528. [CrossRef]

9. Zhou, H.Y.; Wong, M.H. Mercury accumulation in freshwater fish with emphasis on the dietary influence. Water Res. 2000, 34, 4234-4242. [CrossRef]

10. Mason, R.P.; Laporte, J.-M.; Andres, S. Factors controlling the bioaccumulation of mercury, methylmercury, arsenic, selenium, and cadmium by freshwater invertebrates and fish. Arch. Environ. Contam. Toxicol. 2000, 38, 283-297. [CrossRef]

11. van der Oost, R.; Beyer, J.; Vermeulen, N.P.E. Fish bioaccumulation and biomarkers in environmental risk assessment: A review. Environ. Toxicol. Pharmacol. 2003, 13, 57-149. [CrossRef]

12. Berntssen, M.; Hylland, K.; Julshamn, K.; Lundebye, A.K.; Waagbø, R. Maximum limits of organic and inorganic mercury in fish feed. Aquac. Nutr. 2004, 10, 83-97. [CrossRef]

13. Depew, D.C.; Basu, N.; Burgess, N.M.; Campbell, L.M.; Evers, D.C.; Grasman, K.A.; Scheuhammer, A.M. Derivation of screening benchmarks for dietary methylmercury exposure for the common loon (Gavia immer): Rationale for use in ecological risk assessment. Environ. Toxicol. Chem. 2012, 31, 2399-2407. [CrossRef] [PubMed]

14. Eneji, I.S.; Sha'Ato, R.; Annune, P. Bioaccumulation of heavy metals in fish (Tilapia zilli and Clarias gariepinus) organs from River Benue, North-Central Nigeria. Pak. J. Anal. Environ. Chem. 2011, 12, 1-2.

15. Harmelin-Vivien, M.; Cossa, D.; Crochet, S.; Bănaru, D.; Letourneur, Y.; Mellon-Duval, C. Difference of mercury bioaccumulation in red mullets from the north-western Mediterranean and Black seas. Mar. Pollut. Bull. 2009, 58, 679-685. [CrossRef] [PubMed]

16. Piraino, M.N.; Taylor, D.L. Bioaccumulation and trophic transfer of mercury in striped bass (Morone saxatilis) and tautog (Tautoga onitis) from the Narragansett Bay (RI, USA). Environ. Res. 2009, 67, 117-128. [CrossRef]

17. Willacker, J.J.; Eagles-Smith, C.A.; Ackerman, J.T. Mercury bioaccumulation in estuarine fishes: Novel insights from sulfur stable isotopes. Environ. Sci. Technol. 2017, 51, 2131-2139. [CrossRef] [PubMed]

18. Evans, D.W.; Kathman, R.D.; Walker, W.W. Trophic accumulation and depuration of mercury by blue crabs (Callinectes sapidus) and pink shrimp (Penaeus duorarum). Mar. Environ. Res. 2000, 49, 419-434. [CrossRef]

19. Belger, L.; Forsberg, B.R. Factors controlling Hg levels in two predatory fish species in the Negro river basin, Brazilian Amazon. Sci. Total Environ. 2006, 367, 451-459. [CrossRef]

20. Monterroso, P.; Abreu, S.N.; Pereira, E.; Vale, C.; Duarte, A.C. Estimation of Cu, Cd and Hg transported by plankton from a contaminated area (Ria de Aveiro). Acta Oecol. 2003, 24, S351-S357. [CrossRef]

21. Jimmy De, L.; María del, C.C.; Francisco, M. Nanoplastics in the environment and the effects on the zebrafish. Am. J. Eng. Appl. Sci. 2019, 12, 472-475. [CrossRef]

22. Oliveira Ribeiro, C.A.; Nathalie, M.; Gonzalez, P.; Yannick, D.; Jean-Paul, B.; Boudou, A.; Massabuau, J.C. Effects of dietary methylmercury on zebrafish skeletal muscle fibres. Environ. Toxicol. Pharmacol. 2008, 25, 304-309. [CrossRef] [PubMed]

23. Clarkson, T.W.; Magos, L. The toxicology of mercury and its chemical compounds. Crit. Rev. Toxicol. 2006, 36, 609-662. [CrossRef] [PubMed]

24. Havelková, M.; Dušek, L.; Némethová, D.; Poleszczuk, G.; Svobodová, Z. Comparison of mercury distribution between liver and muscle-A biomonitoring of fish from lightly and heavily contaminated localities. Sensors 2008, 8, 4095. [CrossRef] [PubMed]

25. Simon, O.; Boudou, A. Simultaneous experimental study of direct and direct plus trophic contamination of the crayfish Astacus astacus by inorganic mercury and methylmercury. Environ. Toxicol. Chem. 2001, 20, 1206-1215. [CrossRef] [PubMed] 
26. Georgieva, E.; Yancheva, V.; Stoyanova, S.; Velcheva, I.; Iliev, I.; Vasileva, T.; Bivolarski, V.; Petkova, E.; László, B.; Nyeste, K.; et al. Which is more toxic? Evaluation of the short-term toxic effects of chlorpyrifos and cypermethrin on selected biomarkers in common carp (Cyprinus carpio, Linnaeus 1758). Toxics 2021, 9, 125. [CrossRef] [PubMed]

27. Vieira, H.C.; Morgado, F.; Soares, A.M.V.M.; Abreu, S.N. Fish consumption recommendations to conform to current advice in regard to mercury intake. Environ. Sci. Pollut. Res. 2015, 22, 9595-9602. [CrossRef]

28. Amlund, H.; Lundebye, A.-K.; Berntssen, M.H. Accumulation and elimination of methylmercury in Atlantic cod (Gadus morhua L.) following dietary exposure. Aquat. Toxicol. 2007, 83, 323-330. [CrossRef]

29. Amlund, H.; Lundebye, A.-K.; Boyle, D.; Ellingsen, S. Dietary selenomethionine influences the accumulation and depuration of dietary methylmercury in zebrafish (Danio rerio). Aquat. Toxicol. 2015, 158, 211-217. [CrossRef]

30. Streets, D.G.; Horowitz, H.M.; Jacob, D.J.; Lu, Z.; Levin, L.; Ter Schure, A.F.; Sunderland, E.M. Total mercury released to the environment by human activities. Environ. Sci. Technol. 2017, 51, 5969-5977. [CrossRef]

31. Obrist, D.; Kirk, J.L.; Zhang, L.; Sunderland, E.M.; Jiskra, M.; Selin, N.E. A review of global environmental mercury processes in response to human and natural perturbations: Changes of emissions, climate, and land use. Ambio 2018, 47, 116-140. [CrossRef]

32. Cerveny, D.; Roje, S.; Turek, J.; Randak, T. Fish fin-clips as a non-lethal approach for biomonitoring of mercury contamination in aquatic environments and human health risk assessment. Chemosphere 2016, 163, 290-295. [CrossRef] [PubMed]

33. Olmedo, P.; Pla, A.; Hernández, A.F.; Barbier, F.; Ayouni, L.; Gil, F. Determination of toxic elements (mercury, cadmium, lead, tin and arsenic) in fish and shellfish samples. Risk assessment for the consumers. Environ. Int. 2013, 59, 63-72. [CrossRef]

34. Kalueff, A.V.; Stewart, A.M.; Gerlai, R. Zebrafish as an emerging model for studying complex brain disorders. Trends Pharmacol. Sci. 2014, 35, 63-75. [CrossRef]

35. FDA. Zebrafish Make a Splash in FDA Research. 2013. Available online: https://www.fda.gov/consumers/consumer-updates/ zebrafish-make-splash-fda-research (accessed on 5 June 2021).

36. OECD. Test No. 305: Bioaccumulation in fish: Aqueous and dietary exposure. In OECD Guidelines for the Testing of Chemicals; OECD: Paris, France, 2012.

37. Costley, C.T.; Mossop, K.F.; Dean, J.R.; Garden, L.M.; Marshall, J.; Carroll, J. Determination of mercury in environmental and biological samples using pyrolysis atomic absorption spectrometry with gold amalgamation. Anal. Chim. Acta 2000, 405, 179-183. [CrossRef]

38. Kwon, S.Y.; Blum, J.D.; Chirby, M.A.; Chesney, E.J. Application of mercury isotopes for tracing trophic transfer and internal distribution of mercury in marine fish feeding experiments. Environ. Toxicol. Chem. 2013, 32, 2322-2330. [CrossRef]

39. Liu, X.; Jiang, J.; Yan, Y.; Dai, Y.; Deng, B.; Ding, S.; Su, S.; Sun, W.; Li, Z.; Gan, Z. Distribution and risk assessment of metals in water, sediments, and wild fish from Jinjiang River in Chengdu, China. Chemosphere 2018, 196, 45-52. [CrossRef] [PubMed]

40. Viana, L.F.; Cardoso, C.A.L.; Lima-Junior, S.E.; Súarez, Y.R.; Florentino, A.C. Bioaccumulation of metal in liver tissue of fish in response to water toxicity of the Araguari-Amazon River, Brazil. Environ. Monit. Assess. 2020, 192, 781. [CrossRef] [PubMed]

41. Petrakis, G.; Stergiou, K.I. Weight-length relationships for 33 fish species in Greek waters. Fish. Res. 1995, 21, 465-469. [CrossRef]

42. Morgan, M.J. The relationship between fish condition and the probability of being mature in American plaice ( Hippoglossoides platessoides ). ICES J. Mar. Sci. 2004, 61, 64-70. [CrossRef]

43. James, R.; Sampath, K.; Devakiamma, G. Accumulation and depuration of mercury in a catfish Heteropneustes fossilis (Pisces: Heteropneustidae) exposed to sublethal doses of the element. Asian Fish. Sci. Metro Manila 1993, 6, 183-191.

44. Storelli, M.; Giacominelli-Stuffler, R.; Storelli, A.; Marcotrigiano, G. Accumulation of mercury, cadmium, lead and arsenic in swordfish and bluefin tuna from the Mediterranean Sea: A comparative study. Mar. Pollut. Bull. 2005, 50, 1004-1007. [CrossRef]

45. Nyeste, K.; Dobrocsi, P.; Czeglédi, I.; Czédli, H.; Harangi, S.; Baranyai, E.; Simon, E.; Nagy, S.A.; Antal, L. Age and diet-specific trace element accumulation patterns in different tissues of chub (Squalius cephalus): Juveniles are useful bioindicators of recent pollution. Ecol. Indic. 2019, 101, 1-10. [CrossRef]

46. Stoyanova, S.; Georgieva, E.; Velcheva, I.; Iliev, I.; Vasileva, T.; Bivolarski, V.; Tomov, S.; Nyeste, K.; Antal, L.; Yancheva, V. Multi-biomarker assessment in common carp (Cyprinus carpio, Linnaeus 1758) liver after acute chlorpyrifos exposure. Water 2020, 12, 1837. [CrossRef]

47. Vieira, H.C.; Bordalo, M.D.; Rodrigues, A.C.M.; Pires, S.F.S.; Rocha, R.J.M.; Soares, A.M.V.M.; Rendón-von Osten, J.; Abreu, S.N.; Morgado, F. Water temperature modulates mercury accumulation and oxidative stress status of common goby (Pomatoschistus microps). Environ. Res. 2021, 193, 110585. [CrossRef]

48. Garnero, P.L.; Monferran, M.V.; Bistoni de los Angeles, M. Uptake, tissue distribution and elimination in a native fish species Astyanax eigenmanniorum exposed to inorganic mercury. Aquat. Toxicol. 2020, 226, 105567. [CrossRef]

49. Menon, J.S.; Mahajan, S.V. Mercury accumulation in different tissues of fish from Ulhas River Estuary and Thane Creek and the pattern of fish consumption among fish-eaters. Indian J. Geo Mar. Sci. 2013, 42, 812-816.

50. Gonzalez, P.; Dominique, Y.; Massabuau, J.C.; Boudou, A.; Bourdineaud, J.P. Comparative effects of dietary methylmercury on gene expression in liver, skeletal muscle, and brain of the zebrafish (Danio rerio). Environ. Sci. Technol. 2005, 39, 3972-3980. [CrossRef] [PubMed]

51. Feng, C.; Pedrero, Z.; Gentès, S.; Barre, J.; Renedo, M.; Tessier, E.; Berail, S.; Maury-Brachet, R.; Mesmer-Dudons, N.; Baudrimont, M.; et al. Specific pathways of dietary methylmercury and inorganic mercury determined by mercury speciation and isotopic composition in zebrafish (Danio rerio). Environ. Sci. Technol. 2015, 49, 12984-12993. [CrossRef] 
52. Van Walleghem, J.L.A.; Blanchfield, P.J.; Hintelmann, H. Elimination of mercury by yellow perch in the wild. Environ. Sci. Technol. 2007, 41, 5895-5901. [CrossRef]

53. Oliveira Ribeiro, C.A.; Guimarães, J.R.D.; Pfeiffer, W.C. Accumulation and distribution of inorganic mercury in a tropical fish (Trichomycterus zonatus). Ecotoxicol. Environ. Saf. 1996, 34, 190-195. [CrossRef] [PubMed]

54. Abreu, S.; Rodrigues, A.; Gadelha, J.; Morgado, F.; Soares, A. Mercury depuration in Pomatoschistus microps during acclimatation. In Interdisciplinary Studies on Environmental Chemistry-Biological Responses to Contaminants: From Molecular to Community Level; Hamamura, N., Suzuki, S., Mendo, S., Barroso, C.M., Iwata, H., Tanabe, S., Eds.; CESAM \& Departamento de Biologia, Universidade de Aveiro: Aveiro, Portugal, 2010; pp. 159-164.

55. Pato, P.; Válega, M.; Pereira, E.; Vale, C.; Duarte, A.C. Inputs from a mercury-contaminated lagoon: Impact on the nearshore waters of the Atlantic Ocean. J. Coast. Res. 2008, 2, 28-38. [CrossRef]

56. Raldúa, D.; Díez, S.; Bayona, J.M.; Barceló, D. Mercury levels and liver pathology in feral fish living in the vicinity of a mercury cell chlor-alkali factory. Chemosphere 2007, 66, 1217-1225. [CrossRef] [PubMed]

57. Karlsson, S.; Meili, M.; Bergström, U. Bioaccumulation Factors in Aquatic Ecosystems. A Critical Review; Report No. SKB R-02-36; Swedish Nuclear Fuel and Waste Management Co.: Stockholm, Sweden, 2002.

58. Peng, X.; Liu, F.; Wang, W.X. Organ-specific accumulation, transportation, and elimination of methylmercury and inorganic mercury in a low Hg accumulating fish. Environ. Toxicol. Chem. 2016, 35, 2074-2083. [CrossRef] [PubMed]

59. Nigro, M.; Campana, A.; Lanzillotta, E.; Ferrara, R. Mercury exposure and elimination rates in captive bottlenose dolphins. Mar. Pollut. Bull. 2002, 44, 1071-1075. [CrossRef]

60. King, D.G.; Davies, I.M. Laboratory and field studies of the accumulation of inorganic mercury by the mussel Mytilus edulis (L.). Mar. Pollut. Bull. 1987, 18, 40-45. [CrossRef] 